University of Nebraska - Lincoln

DigitalCommons@University of Nebraska - Lincoln

\title{
Quantifying Actual and Theoretical Ethanol Yields for Switchgrass Strains Using NIRS Analyses
}

\author{
Kenneth P. Vogel \\ University of Nebraska-Lincoln, kvogel1@unl.edu \\ Bruce S. Dien \\ USDA-ARS, Bruce.Dien@ars.usda.gov \\ Hans G. Jung \\ USDA-ARS \\ Michael D. Casler \\ US Dairy Forage Research Center, michael.casler@ars.usda.gov \\ Steven D. Masterson \\ USDA-ARS, Steve.Masterson@ars.usda.gov \\ See next page for additional authors
}

Follow this and additional works at: https://digitalcommons.unl.edu/usdaarsfacpub

Vogel, Kenneth P.; Dien, Bruce S.; Jung, Hans G.; Casler, Michael D.; Masterson, Steven D.; and Mitchell, Robert B., "Quantifying Actual and Theoretical Ethanol Yields for Switchgrass Strains Using NIRS Analyses" (2011). Publications from USDA-ARS / UNL Faculty. 1303.

https://digitalcommons.unl.edu/usdaarsfacpub/1303

This Article is brought to you for free and open access by the U.S. Department of Agriculture: Agricultural Research Service, Lincoln, Nebraska at DigitalCommons@University of Nebraska - Lincoln. It has been accepted for inclusion in Publications from USDA-ARS / UNL Faculty by an authorized administrator of DigitalCommons@University of Nebraska - Lincoln. 
Authors

Kenneth P. Vogel, Bruce S. Dien, Hans G. Jung, Michael D. Casler, Steven D. Masterson, and Robert B. Mitchell 


\title{
Quantifying Actual and Theoretical Ethanol Yields for Switchgrass Strains Using NIRS Analyses
}

\author{
Kenneth P. Vogel • Bruce S. Dien • Hans G. Jung • \\ Michael D. Casler • Steven D. Masterson • \\ Robert B. Mitchell
}

Published online: 21 August 2010

(C) US Government 2010

This article is a U.S. government work, and is not subject to copyright in the United States.

\begin{abstract}
Quantifying actual and theoretical ethanol yields from biomass conversion processes such as simultanteous saccharification and fermentation (SSF) requires expensive, complex fermentation assays, and extensive compositional analyses of the biomass sample. Near-infrared reflectance spectroscopy (NIRS) is a non-destructive technology that can be used to obtain rapid, low-cost, high-throughput, and accurate estimates of agricultural product composition. In
\end{abstract}

For abbreviations used in this paper, please refer to Table 1.

USDA neither guarantees nor warrants the standard of the product, and the use of the name by USDA implies no approval of the product to the exclusion of others that may also be suitable.

Ms. Patricia O'Bryan and Mr. Ted Joe are acknowledged for their excellent technical support in conducting the laboratory fermentation and composition experiments.

K. P. Vogel $(\bowtie) \cdot$ S. D. Masterson • R. B. Mitchell

Grain, Forage, and Bioenergy Research Unit,

Agricultural Research Service,

US Department of Agriculture (USDA-ARS),

University of Nebraska,

137 Keim Hall, P.O. Box 830937, Lincoln, NE 68583-0937, USA

e-mail: Ken.Vogel@ars.usda.gov

B. S. Dien

Fermentation Biotechnology Research Unit,

National Center for Agricultural Utilization Research,

USDA-ARS,

1815 N. University Street,

Peoria, IL 61604, USA

H. G. Jung

Plant Science Research Unit, USDA-ARS,

411 Borlaug Hall, 1991 Upper Buford Circle,

St. Paul, MN 55108-6026, USA

M. D. Casler

US Dairy Forage Research Center,

1925 Linden Dr. West,

Madison, WI 53706-1108, USA this study, broad-based NIRS calibrations were developed for switchgrass biomass that can be used to estimate over 20 components including cell wall and soluble sugars and also ethanol production and pentose sugars released as measured using a laboratory SSF procedure. With this information, an additional 13 complex feedstock traits can be determined including theoretical and actual ethanol yields from hexose fermentation. The NIRS calibrations were used to estimate feedstock composition and conversion information for biomass samples from a multi-year switchgrass (Panicum virgatum L.) biomass cultivar evaluation trial. There were significant differences among switchgrass strains for all biomass conversion and composition traits including actual ethanol yields, ETOHL ( $\mathrm{L} \mathrm{Mg}^{-1}$ ) and theoretical ethanol yields, ETOHTL $\left(\mathrm{L} \mathrm{Mg}^{-1}\right)$, based on cell wall and non-cell wall composition NIRS analyses. ETOHL means ranged from 98 to $115 \mathrm{~L} \mathrm{Mg}^{-1}$ while ETOHTL means ranged from 203 to $222 \mathrm{~L} \mathrm{Mg}^{-1}$. Because of differences in both biomass yields and conversion efficiency, there were significant differences among strains for both actual $\left(2,534-3,720 \mathrm{~L} \mathrm{ha}^{-1}\right)$ and theoretical $\left(4,878-7,888 \mathrm{~L} \mathrm{ha}^{-1}\right)$ ethanol production per hectare. It should be feasible to improve ethanol yields per hectare by improving both biomass yield and conversion efficiency by using NIRS analyses to quantify differences among cultivars and management practices.

Keywords Switchgrass · Biomass · Ethanol · NIRS · Quality

\section{Introduction}

High-yielding perennial grasses such as switchgrass (Panicum virgatum $\mathrm{L}$.) have the potential to become valuable biomass energy crops that can be grown on marginal cropland. Agricultural products in general vary in composition and 
other properties due to genetics, growth environment, crop management, harvest practices, and post-harvest storage and processing. Biomass produced for conversion to bioenergy will vary due to the same factors. The quality of agricultural products affects their use for food, animal feed, fiber, and industrial products. Likewise, biomass quality will affect its value for conversion to energy at a biorefinery. Maize (Zea mays L.) grain, which is more homogenous in properties and composition and is much simpler to process to ethanol than herbaceous biomass, is routinely assayed for quality at the biorefinery gate. Quantifying the actual and theoretical ethanol yields from biochemical conversion routes of biomass, such as simultaneous saccharification and fermentation (SSF), requires expensive and complex assays. Fast, inexpensive methods with high accuracy are needed for predicting maximum ethanol yields and actual conversion efficiencies by agronomists for optimizing feedstock quality via production management, by breeders and geneticists for developing cultivars or hybrids with improved processing capabilities and energy yields per ton, and by biorefineries for quickly measuring quality of each truck load of biomass at the biorefinery gate [1].

Near-infrared spectroscopy (NIRS) is widely applied in agriculture for determining the quality of forages, grains and grain products, oilseeds, coffee, tea, spices, fruits, vegetables, sugarcane, beverages, fats and oils, dairy products, eggs, meat, and other agricultural products [2]. NIRS is also widely used to quantify the composition of agricultural products because it meets the criteria of being accurate, reliable, rapid, non-destructive, and inexpensive. NIRS analysis is an analytical method where analytes are quantified in a sample based on the spectral characteristics of the sample. An analyte is defined here as a substance or chemical constituent of interest [3]. The amount of an analyte is predicted based on the sample's near-infrared reflectance spectra using equations fitted to a calibration set representative of the future samples. Laboratory analyses of the samples in the calibration set are conducted for each of the analytes of interest, the near-infrared reflectance spectra profiles of the samples are determined, and utilizing the laboratory and spectral data, prediction equations are developed and validated using mathematical and statistical procedures described by Shenk and Westerhaus [4], Westerhaus et al. [3] and Wold et al. [5, 6].

Most current commercialization efforts for converting lignocelluloses into liquid biofuels rely on biochemical processing. The complex plant cell wall structure requires initial pre-treatment of the biomass either mechanically, thermally, and possibly in the presence of chemical catalysts to expose the carbohydrates. Following pretreatment, the carbohydrates are enzymatically hydrolyzed and fermented into ethanol using microorganisms capable of fermenting both hexoses and pentoses. The pretreated biomass can be saccharified and fermented into ethanol $[7,8]$. NIRS analysis procedures have been used previously to determine composition of biomass feedstocks [9-13] but to date, NIRS analyses has not been used to determine SSF biomass conversion efficiency. Sanderson et al. [9] determined the chemical composition of both woody and herbaceous biomass feedstocks including switchgrass samples and attempted to development NIRS calibrations for ash, lignin, uronic acid, cell wall sugars, $\mathrm{C}, \mathrm{H}, \mathrm{N}, \mathrm{O}$, and ethanol extractives which were not defined. Their results indicated that a broad-based NIRS calibration could be developed for use with an array of feedstocks but separate NIRS calibrations for different classes of biomass would result in improved accuracy and precision. Lorenz et al. [13] used NIRS analyses to predict the composition of maize (Z. mays L.) corn stover. The maize stover compositional values were then used to estimate theoretical ethanol yield of stover from an array of maize hybrids and lines by using the National Renewable Energy Laboratory's theoretical ethanol yield calculator. The maize hybrids and lines differed significantly for all evaluated traits including theoretical ethanol yields on a mass $\left(\mathrm{L} \mathrm{Mg}^{-1}\right)$ and production area $\left(\mathrm{L} \mathrm{ha}^{-1}\right)$ basis, thereby demonstrating that variability in corn stover composition directly affects potential ethanol production [13]. However, actual sugar or ethanol yields, which will be less than $100 \%$ efficient, were not determined experimentally. The theoretical ethanol yield calculator used by Lorenz et al. [13] does not account for variability in pretreatment effects, enzymatic hydrolysis, or ethanol fermentation yields as indirect consequence of changes in biomass composition and properties. Recently, Lorenzana et al. [14] reported maize stover cell wall composition and efficiency of cell wall glucose release by dilute acid/high temperature pretreatment and enzymatic hydrolysis of recombinant inbred lines using a NIRS calibration developed as part of their study, but again actual ethanol production was not measured.

This study had two primary objectives. The first was to develop broad-based NIRS calibrations for all major compositional components of switchgrass biomass and switchgrass biomass ethanol and released pentose yields from a laboratory SSF process using commercial cellulases and Saccharomyces cerevisiae. Composition information was needed to estimate theoretical maximum ethanol yields. The second objective was to determine if switchgrass cultivars and experimental strains adapted to the Midwest USA differ significantly in their actual and potential ethanol yields per ton and hectare. To address this objective, switchgrass samples from a multi-year biomass yield trial were analyzed using the NIRS prediction equations to obtain estimates of the biomass constituents and ethanol and released pentose yields. The 
biomass yield data from the trial along with the ethanol conversion data were used to determine ethanol yields per hectare.

\section{Materials and Methods}

\section{Development of NIRS Calibrations}

The switchgrass biomass samples that were used to develop broad-based NIRS calibrations are representative of the potential range in switchgrass biomass quality that could be produced under different management and harvesting systems with currently available cultivars and experimental strains. The biomass samples were from the following studies and had been analyzed previously for forage quality traits.

(a) A 2-year study at Mead, NE and Ames, IA in which $6 \mathrm{~N}$ fertilizer rates $\left(0,60,120,180,240\right.$, and $\left.300 \mathrm{~kg} \mathrm{ha}^{-1} \mathrm{~N}\right)$ and eight maturity stages at harvest, which ranged from boot stage harvest in late June to an end-of-growing season harvest after a killing frost, were evaluated [15].

(b) A study in which 20 upland and lowland cultivars or experimental strains were evaluated for biomass yield at five locations (Spooner and Arlington, WI, Mead, NE, Manhattan, KS, and Stillwater, OK) over a 2-year period [16] when harvest maturity ranged from R1 (late boot stage) to R5 (post-anthesis) as described by Moore et al. [17].

(c) A long-term $\mathrm{C}$ sequestration study near Mead, NE in which switchgrass samples were collected from two switchgrass cultivars grown with $3 \mathrm{~N}$ rates $(0,60$, and $120 \mathrm{~kg} \mathrm{ha}^{-1} \mathrm{~N}$ ) and harvested either at anthesis or after a killing frost [18].

(d) Samples from a field trial near Mead, NE in which switchgrass hybrids were harvested at the RO (boot stage) to R3 maturity stage [19].

(e) Biomass samples from a half-sib family breeding nursery located near Mead, NE which were harvested at the R2 to R4 maturity stages.

Samples were prepared following the sample preparation guidelines outlined by Murray and Cowe [20]. Specifically, for each of the above studies, biomass samples were collected at harvest and dried in forced-air ovens at $60^{\circ} \mathrm{C}$. The switchgrass biomass samples were ground through a 2-mm screen in a Wiley mill and then re-ground in a cyclone-type mill to pass a 1-mm screen. Ground samples were scanned using a Model 6500 near-infrared spectrometer (NIRSystems, Silver Springs, MD; now FOSS NIRSystems, Inc., Laurel, MD). A set of 482 samples were selected from the above experiments which represented the range of plant maturities, cultivars, ecotypes, fertility rates, and environ- ments of the samples in the five experiments. NIRS software analyses procedures were used to select a calibration set of 112 samples from these experiments that represented the spectral diversity of the samples using procedures described by Shenk and Westerhaus [4] and Westerhaus et al. [3]. This was accomplished using the "Center" and "Select" modules of WINISI II ${ }^{1}$ version 1.04 software from Infrasoft International LLC, State College, PA which is available through Foss NIRSystems Inc ${ }^{1}$. A switchgrass standard sample from the Lincoln ARS Forage Quality Laboratory was also included in the calibration set.

The calibration set of samples were analyzed for chemical composition, ethanol and pentose sugar yields following pretreatment and SSF, and forage quality traits on an oven dry weight basis. Dry matter concentration was determined on subsamples that were not used for other analyses by heating in a forced-air oven for $24 \mathrm{~h}$ at $105^{\circ} \mathrm{C}$. Analytical methods and calculations and abbreviations for all traits are shown in Table 1. Depending on the specific analysis, each sample was analyzed in duplicate or triplicate and the laboratory mean value for that sample was used to develop the NIRS calibration. Additional details and discussion on the laboratory procedures are available in Dien [21].

\section{Compositional Analysis}

Total nitrogen $(\mathrm{N})$ and carbon (C) concentration were determined in the University of Nebraska Agronomy and Horticultural Department's analytical laboratory by the LECO combustion method (Model FP 428 and FP 2000, LECO Corp., St. Joseph, MI) [22, 23]. Lipid content (EE) was determined by exhaustive extraction with diethyl ether [24]. Total mineral or ash content (ASH) was measured as loss of weight after combustion at $450^{\circ} \mathrm{C}$ for $16 \mathrm{~h}$ in a muffle furnace. Carbohydrates and lignin were determined using a sequential procedure as outlined by Dien et al. [25] Soluble carbohydrates were extracted with $80 \% v / v$ ethanol at $60^{\circ} \mathrm{C}$ overnight [26]. The supernatant was analyzed by high-performance liquid chromatography (HPLC) for monosaccharides (glucose and fructose) and oligosaccharides (sucrose, stachyose, and raffinose) using a refractive index detector [25]. Fructans were not measured on the samples because no fructans were found in switchgrass by Dien et al. [25]. The alcohol-insoluble residue was treated with heat-stable $\alpha$-amylase and amyloglucosidase in $0.1 \mathrm{M}$ acetate buffer, $\mathrm{pH}$ 5, to release glucose from starch [27]. Sufficient $95 \% v / v$ ethanol was added to reach an alcohol concentration of $80 \%$, after which the supernatant was removed and analyzed by HPLC for glucose released from starch. The remaining crude, alcohol-insoluble cell wall residue was subjected to a two-stage sulfuric acid hydrolysis using the Uppsala Total Dietary Fiber Method [27]. An aliquot from the first stage of the acid hydrolysis was 
Table 1 Switchgrass biomass composition, and actual and potential ethanol yield traits determined by laboratory analysis or calculation, and references for the methods

\begin{tabular}{|c|c|c|c|}
\hline Variable & Abbreviation & Units & Reference or equation \\
\hline \multicolumn{4}{|l|}{ Composition variables } \\
\hline Dry matter & $\mathrm{DM}$ & $\mathrm{mg} \mathrm{g}^{-1}$ & Vogel et al. [34] \\
\hline Carbon & $\mathrm{C}$ & $\mathrm{mg} \mathrm{g}^{-1}$ & Watson and Isaac [23] \\
\hline Nitrogen & $\mathrm{N}$ & $\mathrm{mg} \mathrm{g}^{-1}$ & Watson and Isaac [23] \\
\hline Extracted fat & $\mathrm{EE}$ & $\mathrm{mg} \mathrm{g}^{-1}$ & Padmore [24] \\
\hline Minerals (total ash) & ASH & $\operatorname{mg~g~}^{-1}$ & $450^{\circ} \mathrm{C}$ muffle furnace for $6 \mathrm{~h}$. \\
\hline Klason lignin & KL & $\mathrm{mg} \mathrm{g}^{-1}$ & Theander et al. [27] \\
\hline Uronic acids $^{\mathrm{a}}$ & UA & $\mathrm{mg} \mathrm{g}^{-1}$ & Theander et al. [27], Ahmed and Labavitch [28] \\
\hline Rhamnose $^{\text {a }}$ & RHA & $\mathrm{mg} \mathrm{g}^{-1}$ & Theander et al. [27] \\
\hline Fucose $^{a}$ & FUC & $\mathrm{mg} \mathrm{g}^{-1}$ & Theander et al. [27] \\
\hline Arabinose $^{\text {a }}$ & ARA & $\mathrm{mg} \mathrm{g}^{-1}$ & Theander et al. [27] \\
\hline Xylose $^{\mathrm{a}}$ & XYL & $\mathrm{mg} \mathrm{g}^{-1}$ & Theander et al. [27] \\
\hline Mannose $^{a}$ & MAN & $\mathrm{mg} \mathrm{g}^{-1}$ & Theander et al. [27] \\
\hline Galactose $^{\mathrm{a}}$ & GAL & $\mathrm{mg} \mathrm{g}^{-1}$ & Theander et al. [27] \\
\hline Glucose $^{\mathrm{a}}$ & GLC & $\mathrm{mg} \mathrm{g}^{-1}$ & Theander et al. [27] \\
\hline$p$-Coumarate esters & PCA & $\mathrm{mg} \mathrm{g}^{-1}$ & Jung and Shalita-Jones [30] \\
\hline Esterified ferulates & FEST & $\mathrm{mg} \mathrm{g}^{-1}$ & Jung and Shalita-Jones [30] \\
\hline Etherified ferulates & FETH & $\mathrm{mg} \mathrm{g}^{-1}$ & Iiyama et al. [29] \\
\hline Cell wall concentration & CWC & $\mathrm{mg} \mathrm{g}^{-1}$ & $\begin{array}{l}\mathrm{KL}+\mathrm{UA}+\mathrm{RHA}+\mathrm{FUC}+\mathrm{ARA}+\mathrm{XYL}+\mathrm{MAN}+\mathrm{GAL}+\mathrm{GLC}+ \\
\mathrm{PCA}+\mathrm{FEST}+\mathrm{FETH}\end{array}$ \\
\hline $\mathrm{ARA}+\mathrm{XYL}+\mathrm{Man}+\mathrm{GAL}$ & AXMG & $\mathrm{mg} \mathrm{g}^{-1}$ & $\mathrm{ARA}+\mathrm{XYL}+\mathrm{MAN}+\mathrm{GAL}$ \\
\hline $\mathrm{ARA}+\mathrm{XYL}$ & $\mathrm{AX}$ & $m g \mathrm{~g}^{-1}$ & $\mathrm{ARA}+\mathrm{XYL}$ \\
\hline Sucrose & SUC & $\mathrm{mg} \mathrm{g}^{-1}$ & Dien et al. [25] \\
\hline Soluble glucose & GLCS & $\mathrm{mg} \mathrm{g}^{-1}$ & Dien et al. [25] \\
\hline Fructose & FRU & $\mathrm{mg} \mathrm{g}^{-1}$ & Dien et al. [25] \\
\hline Total soluble carbohydrates & $\mathrm{SC}$ & $\mathrm{mg} \mathrm{g}^{-1}$ & $\mathrm{SUC}+\mathrm{GLCS}+\mathrm{FRU}$ \\
\hline Starch & STA & $\mathrm{mg} \mathrm{g}^{-1}$ & Dien et al. [25] \\
\hline Non-structural carbohydrates $($ starch $+\mathrm{SC})$ & NSC & $\mathrm{mg} \mathrm{g}^{-1}$ & $\mathrm{SC}+\mathrm{STA}$ \\
\hline Total hexoses & HEX & $\mathrm{mg} \mathrm{g}^{-1}$ & $((\mathrm{MAN}+\mathrm{GAL}+\mathrm{GLC})(180 / 162))+\mathrm{NSC}$ \\
\hline Total sugars & SUG & $\mathrm{mg} \mathrm{g}^{-1}$ & $\mathrm{HEX}+((\mathrm{AX})(150 / 132))$ \\
\hline \multicolumn{4}{|l|}{ Ethanol and potential ethanol } \\
\hline Ethanol/g dry forage & ETOH & $\mathrm{mg} \mathrm{g}^{-1}$ & $\mathrm{SSF}^{\mathrm{b}}$, see "Materials and Methods" section for details. \\
\hline Pentose sugars released/g dry forage & PENT & $\mathrm{mg} \mathrm{g}^{-1}$ & $\mathrm{SSF}^{\mathrm{b}}$, see "Materials and Methods" section for details \\
\hline \multicolumn{4}{|l|}{ Calculated ethanol traits } \\
\hline $\begin{array}{l}\text { Proportion of hexoses that are } \\
\text { non-structural or soluble }\end{array}$ & PSOL & $\%$ & $(\mathrm{NSC} / \mathrm{HEX}) 100$ \\
\hline Pentose proportion of total carbohydrates & PPEN & $\%$ & $(1-(\mathrm{HEX} / \mathrm{SUG})) 100$ \\
\hline $\begin{array}{l}\text { Theoretical ethanol from hexoses } \\
\text { (excluding starch) }\end{array}$ & HEXE & $\mathrm{mg} \mathrm{g}^{-1}$ & {$[(\mathrm{MAN}+\mathrm{GAL}+\mathrm{GLC}) 0.57]+[0.51(\mathrm{GLCS}+\mathrm{FRU})]+[0.537 \mathrm{SUC}]$} \\
\hline $\begin{array}{l}\text { Estimated ethanol from non-structural } \\
\text { carbohydrates }^{\mathrm{c}}\end{array}$ & NSCE & $\mathrm{mg} \mathrm{g}^{-1}$ & $[0.51(\mathrm{GLCS}+\mathrm{FRU})+0.537 \mathrm{SUC}+0.57 \mathrm{STA})] 0.9$ \\
\hline Cell wall ethanol & CWE & $\operatorname{mg~g~}^{-1}$ & ETOH-NSCE \\
\hline $\begin{array}{l}\text { Theoretical ethanol conversion efficiency } \\
\text { from cell wall hexosans }{ }^{\mathrm{d}}\end{array}$ & CWEP & $\%$ & $[\mathrm{CWE} /((\mathrm{MAN}+\mathrm{GAL}+\mathrm{GLC}) 0.57) 0.9)] 100$ \\
\hline Pentoses extraction efficiency & PENTP & $\%$ & {$[0.88 \mathrm{PENT} /(\mathrm{ARA}+\mathrm{XYL})] 100$} \\
\hline Hexose ethanol extraction efficiency & HEXEP & $\%$ & $(\mathrm{ETOH} / \mathrm{HEXE}) 100$ \\
\hline \multicolumn{4}{|l|}{ Forage quality composition } \\
\hline Neutral detergent fiber & NDF & $\mathrm{mg} \mathrm{g}^{-1}$ & Vogel et al. [34] \\
\hline Acid detergent fiber & $\mathrm{ADF}$ & $\mathrm{mg} \mathrm{g}^{-1}$ & Vogel et al. [34] \\
\hline Acid detergent lignin & $\mathrm{ADL}$ & $\mathrm{mg} \mathrm{g}^{-1}$ & ANKOM Technology -9/99 \\
\hline
\end{tabular}


Table 1 (continued)

\begin{tabular}{llll}
\hline Variable & Abbreviation & Units & Reference or equation \\
\hline In vitro dry matter digestibility & IVDMD & $\mathrm{mg} \mathrm{g}^{-1}$ & Vogel et al. [34] \\
Crude protein & $\mathrm{CP}$ & $\mathrm{mg} \mathrm{g}^{-1}$ & $\mathrm{~N} \times 6.25$
\end{tabular}

\footnotetext{
${ }^{a}$ Cell wall carbohydrates

${ }^{b}$ SSF simultaneous saccharification and fermentation using modified procedure of Dowe and McMillan [31] and quantified using HPLC as described by Dien et al. [32]

${ }^{\mathrm{c}}$ Assumed that yeast converts all soluble sugars to ethanol with efficiency of 0.90

${ }^{d}$ Assumed that yeast could covert cell wall hexoses to ethanol with an efficiency of 0.90 . To obtain estimates of $100 \%$ conversion efficiency, multiply by 1.11
}

analyzed for uronic acids [28] using glucuronic acid as the standard. Neutral sugars from the two-stage acid hydrolysis were analyzed as alditol-acetate derivatives by GC-FID. The acid-insoluble residue provided the Klason lignin concentration estimate after correction for ash.

Total (ester and ether linked) ferulates in the cell wall were extracted with $4 \mathrm{M} \mathrm{NaOH}$ for $3 \mathrm{~h}$ at $160^{\circ} \mathrm{C}$ from starch-free, alcohol-insoluble residues [29]. Ester-linked ferulates and $p$-coumarates were extracted from similar starch-free, alcohol insoluble residues with $2 \mathrm{M} \mathrm{NaOH}$ at $39^{\circ} \mathrm{C}$ for $24 \mathrm{~h}$ [30]. Ferulic and $p$-coumaric acid residues in the alkaline extracts were quantified by HPLC [30]. Etherlinked ferulate was calculated as the difference between total and ester-linked ferulic acid concentrations of each sample [29].

\section{Pretreatment and Fermentation}

Flask fermentations were conducted using a simultaneous saccharification and fermentation scheme based upon a modified method [31]. For each sample, $1.5 \mathrm{~g}$ of biomass was mixed with $8.5 \mathrm{ml}$ of sulfuric acid solution $(1.75 \% \mathrm{w} / \mathrm{v})$ and reacted at $121^{\circ} \mathrm{C}$ for an hour using an autoclave. Samples were pretreated in bottles closed with screw cap lids to prevent water loss. Hydrolysates were adjusted to pH 4.5 by adding $\mathrm{Ca}(\mathrm{OH})_{2}$ to neutralize the mineral acid and $1 \mathrm{M}$ sodium citrate buffer stock diluted to $50 \mathrm{mM}$. Hydrolysates were supplemented with $1 \mathrm{ml}$ of a $10 \times \mathrm{YP}$ stock $(200 \mathrm{~g} / \mathrm{L}$ peptone and $100 \mathrm{~g} / \mathrm{L}$ yeast extract). The hydrolysates were fermented using a simultaneous saccharification and fermentation scheme. Filter sterilized cellulase (5.0 FPU per dry gram biomass, GC220, Genencor Inc., Rochester, NY) and $\beta$-glucosidase (15 U per dry gram biomass, Novo188, Novozymes, Denmark) were added and the cultures were inoculated to an O.D. ${ }_{600}$ of 0.5 using $S$. cerevisiae D5A. The pre-fermentation culture was serially transferred twice, first on YP supplemented with $20 \mathrm{~g} / \mathrm{L}$ glucose and next on YP supplemented with $50 \mathrm{~g} / \mathrm{L}$ glucose. Each time the pre-culture was grown for $18 \mathrm{~h}$ at $35^{\circ} \mathrm{C}$ under agitation $(150 \mathrm{rpm})$ in an incubator shaker. The final culture was concentrated to an O.D.600 of 50. The bottles were topped with screw cap holders with fitted silicone septa, which were pierced with $22 \mathrm{~g}$ stainless steel needles to allow for $\mathrm{CO}_{2}$ exhaust. The fermentations were conducted at $35^{\circ} \mathrm{C}$ for $72 \mathrm{~h}$ while being mixed at $100 \mathrm{rpm}$ using an incubator shaker. Ethanol, sugars, and organic acids were analyzed using a HPLC system equipped with an organic acids column (Bio-Rad Laboratories, CA) and a refractive index detector, as previously described [32]. All samples were analyzed in triplicate.

\section{Forage Quality Analyses}

Crude protein concentration was calculated as $\mathrm{N} \times 6.25$ [33]. In vitro rumen dry matter digestibility (IVDMD), neutral detergent fiber, acid detergent fiber, and acid detergent lignin (ADL) were determined using the ANKOM Fiber Analyzer (ANKOM Technology Corp., Fairport, NY ${ }^{1}$ ) and the procedures described by Vogel et al. [34] and the ANKOM ADL procedure (ANKOM Technology -9/99, Method for Determining Acid Detergent Lignin in Beakers).

\section{NIRS}

The laboratory data were used to develop prediction equations using the procedures described by Westerhaus et al. [3]. The number of samples for which complete laboratory data was available was typically 111 or 112 but for some analytes the number of samples ranged from 102 to 108 . The samples were divided into calibration and validation sets with the validation set having 17 or 18 samples depending upon the analyte. Validation samples were selected to represent the range of the entire sample set. The remaining samples were in the calibration group. Calibration equations for predicting unknowns were developed using the WinISI software modified PLS procedure. The calibration equations were tested using the WinISI software validation procedures by predicting analyte values of the validation set. Calibration equations were selected 
using criteria described by Westerhaus et al. [4] and Shenk and Westerhaus [3]. Once the calibration equation was selected, the validation samples were included in the calibration set and calibration equations were redeveloped using the same math treatments and options as in the original calibrations. This additional calibration work was done to improve the precision and robustness of the calibrations. Calibrations statistics included the coefficient of determination $\left(r^{2}\right)$, standard error of calibration (SEC), standard error of cross-validation (SECV), and standard error of prediction (SEP) values. The $r^{2}$ represents the proportion of the total variation among the samples for a trait that is explained by the calibration. The SEC is the standard error of the difference between the laboratory value and the NIRS-predicted value for the same sample. The SEP is the standard error of the difference between the laboratory value and the NIRS-predicted value of the validation set. SECV is the standard error of the difference between predicted and laboratory values when samples are sequentially removed from the calibration process. Acceptable NIRS calibration equations should have $r^{2}$ values greater than 0.80 , and preferably greater than 0.90 , with small SEC, SEP, and SECV values.

\section{Switchgrass Biomass Cultivar Trial}

The switchgrass cultivar and experimental strain evaluation trial was located in eastern Nebraska at the University of Nebraska's Agricultural Research and Development Center about $50 \mathrm{~km}$ west of Omaha, NE. The trial was a typical small plot trial with 21 cultivars or experimental strains. The trial was planted in 2002 and biomass was harvested in 2003, 2004, and 2005. The experimental design was a randomized complete block with six replicates. Seeded plots were $1.5 \times 3.0 \mathrm{~m}$ and were separated on the ends by a $1.5-\mathrm{m}$ wide alley that was also seeded to switchgrass. No fertilizer was applied the establishment year. In the postestablishment years, the study was fertilized in the spring with $112 \mathrm{~kg} \mathrm{ha}^{-1} \mathrm{~N}\left(\mathrm{NH}_{4} \mathrm{NO}_{3}\right)$. Herbicides were used for weed control. The residual biomass on the plots from the previous year was removed before spring growth initiated by mowing or burning. Plots were harvested for biomass yield in mid-August when most cultivars or experimental strains in the nursery were headed. Maturity of the strains in the nursery ranged from R1 to R4 using the staging system of Moore et al. [17]. Plots were harvested with a plot flail harvester with a cutting height of $10 \mathrm{~cm}$. The harvester cut a $0.91 \mathrm{~m}$ swath down the middle of each plot. Plots were sampled prior to harvest to obtain samples for biomass composition analysis and to determine dry matter concentration. Wet sample weights were added to plot yields to nullify the effect of sub-sample size on biomass yield. Yields are reported on a dry weight basis. The single harvest treatment and $\mathrm{N}$ fertilization rates were based on the results of Vogel et al. [15]. The harvested samples were dried, ground, and used for NIRS analysis with the procedures described above. Prior to predicting the composition of the samples, the NIRS spectra of the samples were analyzed for fitness to the calibration set of samples by using the Global H statistic to test for outliers [20]. All samples in the application set of samples had acceptable $H$ values $(H<3.0)$. The analytes listed in Table 1 were predicted for the samples from the yield test. The feedstock quality data and the yield data was used to calculate ethanol yield, theoretical ethanol yield, and potentially fermentable substrate yield $\left(\mathrm{L} \mathrm{Mg}^{-1}\right) \mathrm{Mg}$ and production per hectare $\left(\mathrm{L} \mathrm{ha}^{-1}\right.$ ) using equations listed below. All data were analyzed using the PROC GLM procedure of PC-SAS for Windows [35]. Strain or cultivars were considered to be fixed effects. With perennials, mean performance over years is of primary importance; therefore, plot means over years were used in the statistical analyses.

Equations for Determining Yield (L) per Ton (Mg) and Production per Hectare $\left(\mathrm{L} \mathrm{Ha}^{-1}\right)$

1. Specific volume of ethanol is $0.789 \mathrm{~g} \mathrm{~mL}^{-1}$ so $1 / 0.789 \mathrm{~g} \mathrm{~mL}^{-1}=1.267 \mathrm{mLg}^{-1}$ ethanol. On a unit basis, $\mathrm{mg} \mathrm{g}^{-1}=\mathrm{g} \mathrm{kg}^{-1}=\mathrm{kg} \mathrm{Mg}^{-1}$.

2. Ethanol from glucan $\left(\mathrm{mL} \mathrm{g}^{-1}\right)$ (or hexosan sugar) $=$ [ $(180 \mathrm{~g}$ of glucose $/ 162 \mathrm{~g}$ of glucan $) \times(0.51 \mathrm{~g}$ ethanol/ $\mathrm{g}$ glucose $)] / 0.789 \mathrm{~g}$ ethanol per $\mathrm{mL}$ [21]. For equation 5 below, note that $((180 / 162) \times 0.51)=0.57$.

3. Ethanol from xylan (or arabinan) $\left(\mathrm{mL} \mathrm{g}^{-1}\right)=$ [ $(150 \mathrm{~g}$ xylose $/ 132 \mathrm{~g}$ of xylan $) \times 0.51 \mathrm{~g}$ ethanol $/ \mathrm{g}$ xylose) $] / 0.789 \mathrm{~g}$ ethanol per $\mathrm{ml}[21]$.

The trait and associated units listed in Table 1 can be inserted into the equations below. Sugars were expressed on an anhydrous basis. Actual ethanol yield via SSF was calculated using the ETOH result. Because the yeast that was used to ferment the released sugars cannot ferment pentose sugars, ETOH was only from reduced hexoses; $1 \mathrm{ha}=10,000 \mathrm{~m}^{2}$.

4. Ethanol yield from SSF released glucose from biomass:

ETOHL $\left(\mathrm{L} \mathrm{Mg}^{-1}\right)=\mathrm{ETOH} \times 1.267$.

5. Theoretical ethanol yield from all biomass hexoses:

$\begin{aligned} \operatorname{HEXEL}\left(\mathrm{L} \mathrm{Mg}^{-1}\right)= & (((\mathrm{MAN}+\mathrm{GAL}+\mathrm{GLC}+\mathrm{STA}) \times 0.57) \\ & +((\mathrm{GLCS}+\mathrm{FRU}) \times 0.51)+(\mathrm{SUC} \times 0.537)) \\ & \times 1.267) ; \text { assuming } 100 \% \text { conversion. }\end{aligned}$ 
6. Ethanol yield from SSF released pentose sugars:

PENTEL $\left(\mathrm{L} \mathrm{Mg}^{-1}\right)=$ PENT $\times 0.51 \times 1.267$

$$
\times 0.8 \text {; assuming } 80 \% \text { conversion. }
$$

7. Theoretical ethanol yield from pentose sugars:

PENTETL $\left(\mathrm{L} \mathrm{Mg}^{-1}\right)=(\mathrm{ARA}+\mathrm{XYL}) \times 0.579 \times 1.267$.

8. Total ethanol yield (ETOHTL) from SSF:

ETOHTL $\left(\mathrm{L} \mathrm{Mg}^{-1}\right)=$ ETOHL + PENTEL.

9. Total ethanol production per ha from SSF:

ETOHTLH $\left(\mathrm{L} \mathrm{ha}^{-1}\right)=$ ETOHTL $\times$ biomass production $\left(\mathrm{Mg} \mathrm{ha}^{-1}\right)$.

10. Total theoretical ethanol yield from all biomass sugars:

ETOHTLT $\left(\mathrm{L} \mathrm{Mg}^{-1}\right)=$ HEXEL + PENTETL.

11. Total theoretical ethanol production from all biomass sugars:

$$
\begin{aligned}
\text { ETOHTLTH }\left(\mathrm{L} \mathrm{ha}^{-1}\right)= & \text { ETOHTLT } \\
& \times \text { biomass production yield }\left(\mathrm{Mg} \mathrm{ha}^{-1}\right) .
\end{aligned}
$$

12. Conversion ratio of actual to theoretical ethanol on a liter-to-liter basis.

\section{$\mathrm{ERATIO}=\mathrm{ETOHTL} / \mathrm{ETOHTLT}$.}

To convert to units used in production agriculture in the USA, the following conversion factors can be used: $L$ ethanol $\mathrm{ha}^{-1} / 9.35=$ gallons acre $^{-1} ; \mathrm{L} \mathrm{Mg}^{-1}$ ethanol $\times 0.24=$ gallons $U . S$ ton $^{-1} ; 1 \mathrm{ha}=2.47$ acres.

\section{Results and Discussion}

\section{Switchgrass NIRS Calibrations}

The calibration set used to develop the NIRS method represented a diverse population as evidenced by the large range in compositional properties (Table 2). Notable examples of properties with wide values include Klason lignin $\left(92-256 \mathrm{mg} \mathrm{g}^{-1}\right)$, cell-wall associated glucans (190$\left.320 \mathrm{mg} \mathrm{g}^{-1}\right)$, and xylan $\left(129.75-238.36 \mathrm{mg} \mathrm{g}^{-1}\right.$ ). These components represent $62.3 \%$ of the average switchgrass biomass. Glucose and xylose content are particularly important because only carbohydrates can be biochemically converted into ethanol. Solubles sugars (e.g., glucose, fructose, and sucrose) were also significant and on average comprised $15 \%$ of the hexose sugars present in switchgrass. Most other major cell wall and soluble carbohydrates also exhibited significant variation. Exceptions included the more minor cell wall components, fucose (FUC) and rhamnose. Most samples did not have detectable levels of fucose. Variation in total carbon (C) was much smaller than for specific carbohydrates, illustrating that while total $\mathrm{C}$ variation is limited, plants display plasticity in the specific form it takes.

Differences in the partitioning of $\mathrm{C}$ between carbohydrates and lignin directly affect the theoretical ethanol yield, which is solely dependent upon total carbohydrates. The theoretical ethanol yield can be calculated for all biomass hexoses, pentoses, and all biomass sugars (see Eqs. 5, 7, and 10) from the carbohydrate composition. Likewise, the partitioning of $\mathrm{C}$ among different carbohydrates can affect the expected ethanol yield depending upon how efficiently the carbohydrates can be extracted (soluble vs. structural) and fermented (hexoses vs. pentoses). In this study, the hexoses were directly fermented to ETOH using a $S$. cerevisiae yeast strain selected for fermentation of cellulosic feedstocks. However, because Saccharomyces yeast does not ferment pentoses, xylose was measured directly in the spent fermentation broth. Approximately, a twofold difference was observed between low and high yielding switchgrass samples for ETOH (60.83-127.34 $\mathrm{g} \mathrm{mg}^{-1}$ ) and pentose (PENT, 116.61 to $255.37 \mathrm{~g} \mathrm{mg}^{-1}$ ) yields. Non-structural sugars (e.g., soluble and storage carbohydrates) are readily extractable and fermented in comparison to those associated with the cell wall. The contribution of ETOH from the non-structural carbohydrates (NSCE) was subtracted from total ETOH to give cell wall associated ethanol (CWE). NSCE was calculated by using an estimated $90 \%$ conversion efficiency for glucose and starch yeast fermentations. The CWE had a significantly lower mean value $\left(66.88 \mathrm{~g} \mathrm{mg}^{-1}\right)$ than ETOH $\left(91.86 \mathrm{~g} \mathrm{mg}^{-1}\right)$, indicating the significant affect of the more easily converted soluble and storage carbohydrates. Ethanol yield is affected by both the amount of carbohydrate present and the efficiency of their extraction and (for hexoses) conversion into ethanol. Conversion efficiency was directly measured by calculating the ratio of the ethanol or pentose yields and the theoretical yields. Pentoses were extracted by the dilute-acid pretreatment with $78.13 \%$ efficiency. By contract, the conversion efficiency of hexoses into ethanol was $50.2 \%$ and we estimate only $47.0 \%$ conversion efficiency for cell wall hexoses which are primarily from cellulose. The lower efficiencies for glucans compared to pentoses reflect in part the yield lost to ethanol production by 
Table 2 Mean, standard deviation, and range values for switchgrass samples in the bioenergy NIRS calibration data set

\begin{tabular}{|c|c|c|c|c|c|}
\hline Composition variables ${ }^{a}$ & Units & Mean & Standard deviation & Minimum & Maximum \\
\hline DM & $\mathrm{mg} \mathrm{g}^{-1}$ & 905 & 9 & 858 & 929 \\
\hline $\mathrm{C}$ & $\mathrm{mg} \mathrm{g}^{-1}$ & 438.7 & 6.4 & 417.2 & 450.1 \\
\hline $\mathrm{N}$ & $\mathrm{mg} \mathrm{g}^{-1}$ & 9.5 & 4.8 & 2.0 & 22.8 \\
\hline $\mathrm{EE}$ & $\mathrm{mg} \mathrm{g}^{-1}$ & 10.2 & 3.9 & 2.0 & 23.0 \\
\hline $\mathrm{ASH}$ & $\mathrm{mg} \mathrm{g}^{-1}$ & 76.9 & 15.7 & 1.1 & 118.3 \\
\hline KL & $\mathrm{mg} \mathrm{g}^{-1}$ & 166.1 & 32.6 & 92.0 & 256.3 \\
\hline UA & $\mathrm{mg} \mathrm{g}^{-1}$ & 15.8 & 1.8 & 12.03 & 23.1 \\
\hline RHA & $\mathrm{mg} \mathrm{g}^{-1}$ & 1.4 & 0.7 & 0.4 & 3.7 \\
\hline FUC & $\mathrm{mg} \mathrm{g}^{-1}$ & 0.0 & 0.1 & 0.00 & 0.5 \\
\hline ARA & $\mathrm{mg} \mathrm{g}^{-1}$ & 30.0 & 2.6 & 24.5 & 36.8 \\
\hline XYL & $\mathrm{mg} \mathrm{g}^{-1}$ & 190.8 & 22.9 & 129.8 & 238.4 \\
\hline MAN & $\mathrm{mg} \mathrm{g}^{-1}$ & 6.6 & 3.2 & 2.7 & 23.6 \\
\hline GAL & $\mathrm{mg} \mathrm{g}^{-1}$ & 9.5 & 1.5 & 4.25 & 14.7 \\
\hline GLC & $\mathrm{mg} \mathrm{g}^{-1}$ & 265.7 & 26.7 & 190.4 & 319.8 \\
\hline PCA & $\mathrm{mg} \mathrm{g}^{-1}$ & 5.76 & 1.6 & 2.2 & 11.0 \\
\hline FEST & $\mathrm{mg} \mathrm{g}^{-1}$ & 1.4 & 0.5 & 0.4 & 3.0 \\
\hline FETH & $\mathrm{mg} \mathrm{g}^{-1}$ & 0.8 & 0.6 & 0.0 & 2.4 \\
\hline CWC & $\mathrm{mg} \mathrm{g}^{-1}$ & 693.4 & 60.4 & 543.8 & 816.4 \\
\hline AXMG & $\mathrm{mg} \mathrm{g}^{-1}$ & 234.7 & 31.7 & 178.2 & 287.2 \\
\hline $\mathrm{AX}$ & $\mathrm{mg} \mathrm{g}^{-1}$ & 220.7 & 23.6 & 158.2 & 272.4 \\
\hline SUC & $\mathrm{mg} \mathrm{g}^{-1}$ & 27.5 & 13.7 & 2.08 & 54.8 \\
\hline GLCS & $\mathrm{mg} \mathrm{g}^{-1}$ & 8.3 & 4.9 & 0.3 & 21.4 \\
\hline FRU & $\mathrm{mg} \mathrm{g}^{-1}$ & 10.0 & 6.7 & 0.0 & 34.9 \\
\hline $\mathrm{SC}$ & $\mathrm{mg} \mathrm{g}^{-1}$ & 45.8 & 20.9 & 8.1 & 99.5 \\
\hline STA & $\mathrm{mg} \mathrm{g}^{-1}$ & 7.5 & 8.0 & 0.00 & 47.5 \\
\hline NSC & $\mathrm{mg} \mathrm{g}^{-1}$ & 54.8 & 26.2 & 10.2 & 119.7 \\
\hline HEX & $\mathrm{mg} \mathrm{g}^{-1}$ & 366.8 & 26.6 & 302.0 & 430.2 \\
\hline SUG & $\mathrm{mg} \mathrm{g}^{-1}$ & 617.8 & 47.1 & 507.1 & 703.5 \\
\hline PSOL & $\%$ & 15 & 7 & 3 & 32 \\
\hline PPEN & $\%$ & 41 & 2 & 34 & 46 \\
\hline \multicolumn{6}{|c|}{ Ethanol and potential ethanol } \\
\hline $\mathrm{ETOH}$ & $\mathrm{mg} \mathrm{g}^{-1}$ & 91.96 & 14.9 & 60.8 & 127.3 \\
\hline PENT & $\mathrm{mg} \mathrm{g}^{-1}$ & 196.4 & 27.7 & 116.6 & 255.4 \\
\hline HEXE & $\mathrm{mg} \mathrm{g}^{-1}$ & 184.4 & 12.2 & 154.0 & 221.1 \\
\hline NSCE & $\mathrm{mg} \mathrm{g}^{-1}$ & 25.2 & 2.12 & 4.7 & 55.0 \\
\hline CWE & $\mathrm{mg} \mathrm{g}^{-1}$ & 66.9 & 10.3 & 38.7 & 90.7 \\
\hline CWEP & $\%$ & 47.0 & 9.4 & 25.3 & 73.3 \\
\hline PENTP & $\%$ & 78.1 & 6.4 & 58.2 & 93.1 \\
\hline HEXEP & $\%$ & 50.2 & 9.05 & 33.3 & 73.6 \\
\hline \multicolumn{6}{|c|}{ Forage quality composition } \\
\hline NDF & $\mathrm{mg} \mathrm{g}^{-1}$ & 712.7 & 44.0 & 587.7 & 807.9 \\
\hline $\mathrm{ADF}$ & $\mathrm{mg} \mathrm{g}^{-1}$ & 381.8 & 45.2 & 269.3 & 482.0 \\
\hline ADL & $\mathrm{mg} \mathrm{g}^{-1}$ & 54.6 & 12.9 & 10.9 & 84.34 \\
\hline IVDMD & $\mathrm{mg} \mathrm{g}^{-1}$ & 495.3 & 81.3 & 290.0 & 714.8 \\
\hline $\mathrm{CP}$ & $\mathrm{mg} \mathrm{g}^{-1}$ & 59.4 & 30.0 & 12.2 & 142.8 \\
\hline
\end{tabular}

${ }^{\mathrm{a}}$ Definitions for all abbreviations are listed in Table 1. 
Table 3 Summary of switchgrass NIRS calibration statistics for bioenergy trait characterization sample set

\begin{tabular}{|c|c|c|c|c|c|c|c|c|}
\hline Abbreviation & Equation type & $\begin{array}{l}\text { Mean } \\
\text { gkg }^{-1}\end{array}$ & $N$ & $\begin{array}{l}\text { SEC } \\
\mathrm{gkg}^{-1}\end{array}$ & $r^{2}$ & $\begin{array}{l}\mathrm{SECV} \\
\mathrm{gkg}^{-1}\end{array}$ & $\begin{array}{l}\text { SEP } \\
\mathrm{gkg}^{-1}\end{array}$ & RPD \\
\hline \multicolumn{9}{|c|}{ Biomass bioenergy variables } \\
\hline \multirow[t]{2}{*}{$\mathrm{C}$} & Combined $^{\mathrm{a}}$ & 439.18 & 104 & 2.14 & 0.86 & 4.17 & & \\
\hline & Cal \& Val. ${ }^{\mathrm{b}}$ & 439.02 & 88 & 3.65 & 0.62 & 5.07 & 4.49 & 1.42 \\
\hline \multirow[t]{2}{*}{$\mathrm{N}$} & Combined & 9.46 & 107 & 0.42 & 0.99 & 0.61 & & \\
\hline & Cal \& Val. & 9.20 & 89 & 0.52 & 0.99 & 0.63 & 0.72 & 6.66 \\
\hline \multirow[t]{2}{*}{$\mathrm{EE}$} & Combined. & 10.26 & 111 & 1.82 & 0.78 & 2.80 & & \\
\hline & Cal \& Val. & 10.08 & 94 & 2.19 & 0.69 & 3.46 & 3.30 & 1.18 \\
\hline \multirow[t]{2}{*}{ ASH } & Combined & 77.45 & 107 & 5.54 & 0.84 & 8.60 & & \\
\hline & Cal \& Val. & 76.40 & 87 & 10.13 & 0.35 & 10.50 & 8.89 & 1.77 \\
\hline \multirow[t]{2}{*}{$\mathrm{KL}$} & Combined & 165.21 & 109 & 10.56 & 0.89 & 20.63 & & \\
\hline & Cal \& Val. & 168.45 & 92 & 10.34 & 0.89 & 22.26 & 25.61 & 1.27 \\
\hline \multirow[t]{2}{*}{ UA } & Combined & 15.73 & 108 & 0.75 & 0.76 & 0.87 & & \\
\hline & Cal \& Val. & 15.67 & 91 & 0.73 & 0.74 & 0.88 & 1.03 & 1.74 \\
\hline \multirow[t]{2}{*}{ RHA } & Combined & 1.44 & 107 & 0.24 & 0.86 & 0.27 & & \\
\hline & Cal \& Val. & 1.45 & 89 & 0.26 & 0.83 & 0.31 & 0.24 & 2.91 \\
\hline \multirow[t]{2}{*}{ FUC } & Combined & 0.10 & 12 & 0.01 & 0.96 & 0.07 & & \\
\hline & Cal \& Val. & 0.10 & 9 & 0.03 & 0.60 & 0.06 & 0.08 & 1.25 \\
\hline \multirow[t]{2}{*}{ ARA } & Combined & 29.85 & 109 & 1.03 & 0.85 & 1.32 & & \\
\hline & Cal \& Val. & 29.99 & 92 & 1.02 & 0.85 & 1.33 & 1.31 & 1.98 \\
\hline \multirow[t]{2}{*}{ XYL } & Combined & 191.00 & 110 & 6.00 & 0.93 & 8.41 & & \\
\hline & Cal \& Val. & 192.24 & 93 & 6.65 & 0.91 & 9.18 & 8.45 & 2.71 \\
\hline \multirow[t]{2}{*}{ MAN } & Combined & 6.53 & 105 & 0.47 & 0.98 & 0.87 & & \\
\hline & Cal \& Val. & 6.65 & 88 & 0.51 & 0.97 & 1.02 & 1.02 & 3.13 \\
\hline \multirow[t]{2}{*}{ GAL } & Combined & 9.55 & 107 & 0.38 & 0.93 & 0.61 & & \\
\hline & Cal \& Val. & 9.54 & 91 & 0.30 & 0.95 & 0.64 & 1.23 & 1.21 \\
\hline \multirow[t]{2}{*}{ GLC } & Combined & 265.90 & 107 & 5.70 & 0.95 & 7.82 & & \\
\hline & Cal \& Val. & 267.45 & 89 & 6.12 & 0.95 & 8.11 & 11.61 & 2.3 \\
\hline \multirow[t]{2}{*}{ PCA } & Combined & 5.66 & 108 & 0.36 & 0.95 & 0.49 & & \\
\hline & Cal \& Val. & 5.69 & 90 & 0.36 & 0.95 & 0.51 & 0.73 & 2.19 \\
\hline \multirow[t]{2}{*}{ FEST } & Combined & 1.42 & 110 & 0.16 & 0.91 & 0.21 & & \\
\hline & Cal \& Val. & 1.41 & 91 & 0.15 & 0.92 & 0.22 & 0.27 & 1.85 \\
\hline \multirow[t]{2}{*}{ FETH } & Combined & 0.82 & 98 & 0.24 & 0.78 & 0.38 & & \\
\hline & Cal \& Val. & 0.78 & 82 & 0.24 & 0.74 & 0.37 & 0.54 & 1.11 \\
\hline \multirow[t]{2}{*}{ CWC } & Combined & 693.60 & 110 & 17.90 & 0.91 & 28.98 & & \\
\hline & Cal \& Val. & 698.87 & 89 & 12.70 & 0.95 & 25.42 & 37.56 & 1.6 \\
\hline \multirow[t]{2}{*}{ AXMG } & Combined & 237.18 & 109 & 6.32 & 0.92 & 8.76 & & \\
\hline & Cal \& Val. & 238.52 & 92 & 6.69 & 0.91 & 9.38 & 11.05 & 2.87 \\
\hline \multirow[t]{2}{*}{$\mathrm{AX}$} & Combined & 220.95 & 109 & 6.62 & 0.92 & 9.04 & & \\
\hline & Cal \& Val. & 222.29 & 92 & 6.05 & 0.93 & 9.00 & 10.53 & 2.24 \\
\hline SUC & Combined & 27.53 & 106 & 3.59 & 0.93 & 5.50 & & \\
\hline & Cal \& Val. & 26.55 & 89 & 3.77 & 0.92 & 5.59 & 6.00 & 2.28 \\
\hline GLCS & Combined & 8.14 & 108 & 1.71 & 0.87 & 2.25 & & \\
\hline & Cal \& Val. & 8.15 & 93 & 2.05 & 0.80 & 2.69 & 3.19 & 1.53 \\
\hline FRU & Combined & 10.13 & 108 & 2.02 & 0.91 & 2.77 & & \\
\hline & Cal \& Val. & 10.30 & 91 & 2.05 & 0.91 & 3.03 & 3.21 & 2.08 \\
\hline $\mathrm{SC}$ & Combined & 45.93 & 109 & 4.72 & 0.95 & 7.23 & & \\
\hline & Cal \& Val. & 45.48 & 89 & 4.41 & 0.95 & 7.64 & $7.01^{\mathrm{d}}$ & 2.98 \\
\hline STA & Combined & 7.08 & 106 & 1.52 & 0.95 & 2.79 & & \\
\hline
\end{tabular}


Table 3 (continued)

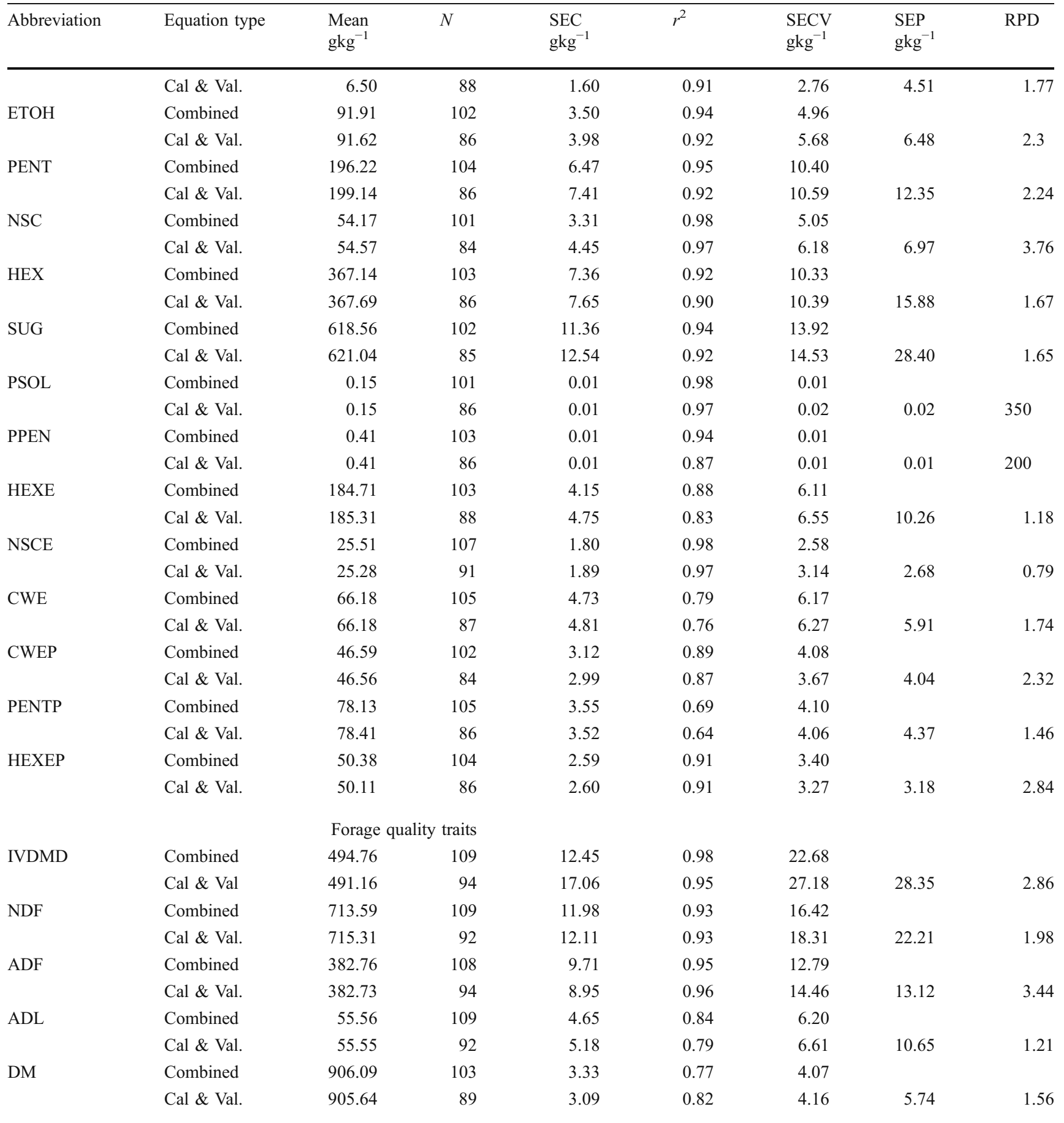

$S E C$ standard error of calibration, $R S Q$ coefficient of determination, $S E C V$ standard error of cross validation, and $S E P$ standard error of prediction, $R P D$ ratio of $\mathrm{SD} / \mathrm{SEP}$

${ }^{\mathrm{a}}$ The upper row (combined) for each variable contains the revised calibration equation on which both calibration and validation samples were included to improve the robustness of the prediction equations

${ }^{\mathrm{b}}$ The lower row for each variable contains the calibration statistics and validations statistics (Cal \& Val) for the calibration set of samples from which the validation set of samples were removed for use as validation samples 
Table 4 Means and range values for biomass yield, forage composition, and energy yield traits of switchgrass cultivars and selected experimental strains from a biomass yield test grown in eastern Nebraska in 2002-2005

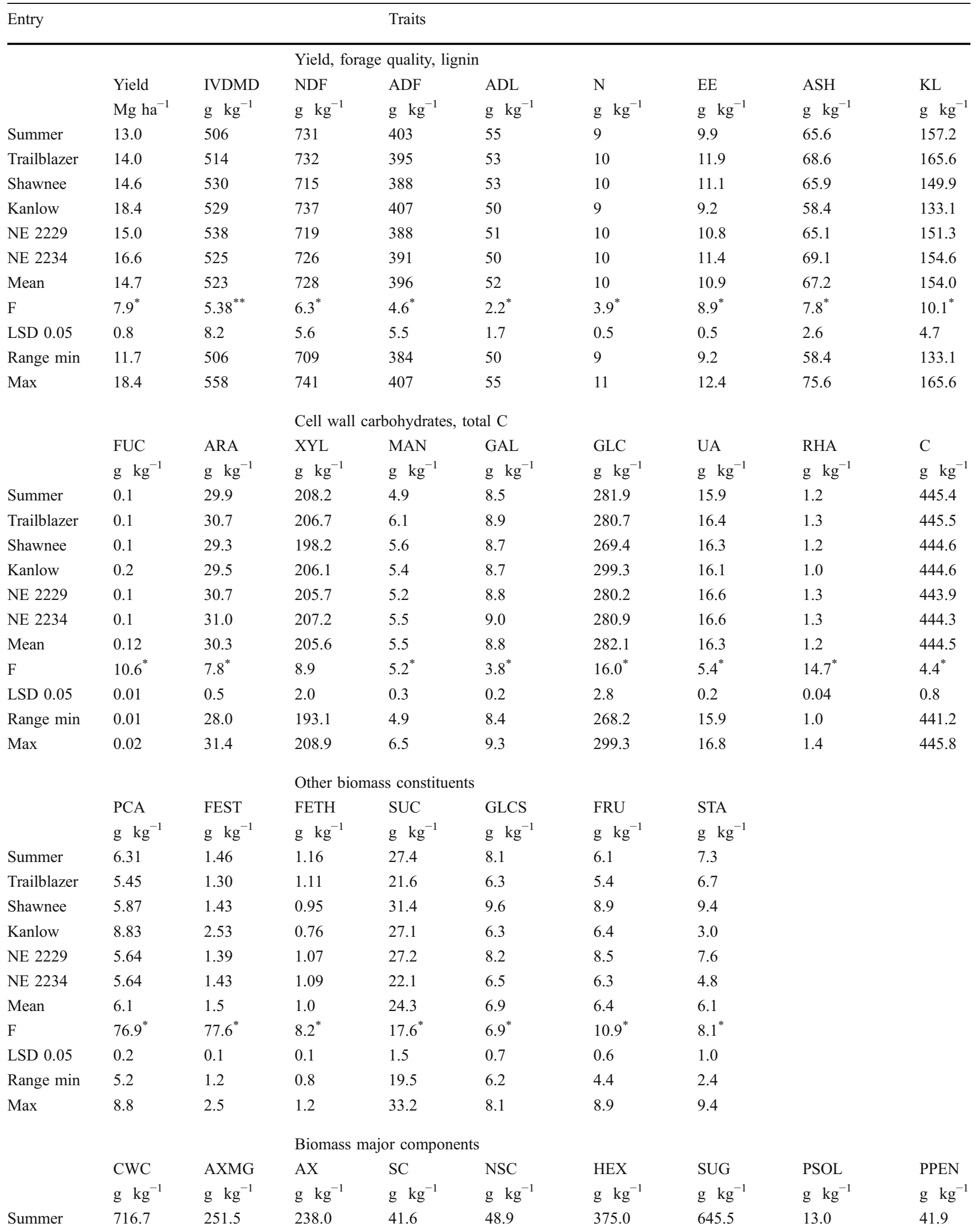


Table 4 (continued)

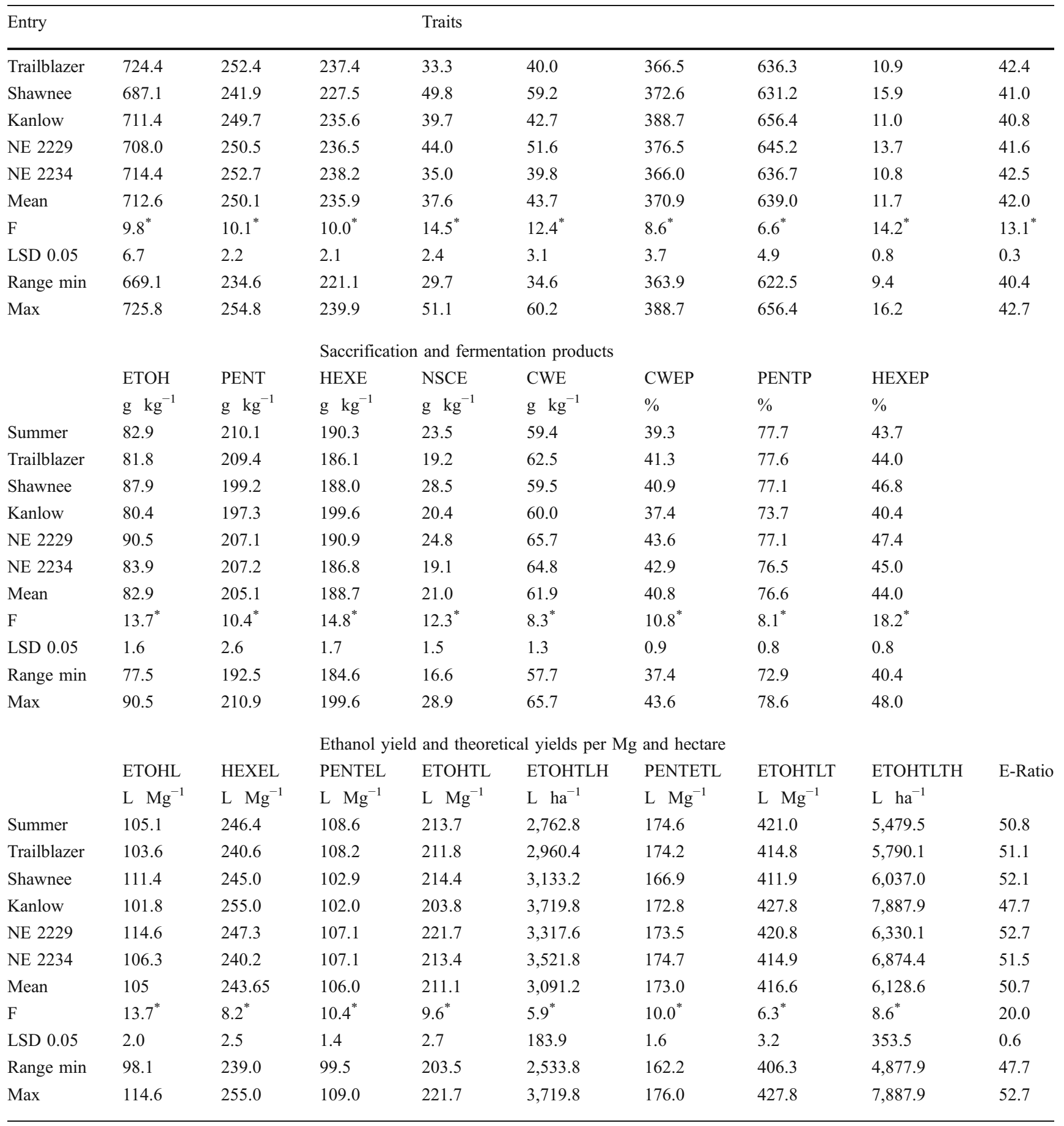

See Table 1 for abbreviation definitions

${ }^{* *} p=0.01$, indicate significance

the yeast but primarily the more recalcitrant nature of the cellulose polymer vs. hemicelluloses.

Good-to-excellent prediction equations were obtained for most traits as indicated by the high $r^{2}$ and low SEC, SEP, and SECV values for the best predictive equations that were developed for each trait (Table 3). Initially, a subset of samples (approximately 20) were removed from the sample set to serve as validation samples. The remaining samples were used to develop the calibrations which were validated using the validation subset (see "Cal \& Val" row for each 
trait in Table 3). With these initial calibrations, the $r^{2}$ values were only less than 0.80 for ASH, EE, C, UA, FUC, FETH, CWE, pentose extraction efficiency (PENTP), and ADL. ASH is typically difficult to predict with NIRS. Based on our experience using NIRS for forage quality traits, it is more difficult to obtain $r^{2}$ values greater than 0.8 if the calibration set has limited variation for the calibration analyte, for analytes that are measured with low precision such as ADL, and for complex traits that include a biochemical reaction step in the analysis procedure such as IVDMD. As discussed previously, there was limited variation for total $\mathrm{C}$ in switchgrass biomass for which the range was $858-939 \mathrm{mg} \mathrm{g}^{-1}$. CWE and PENTP are complex traits because of the SSF process. The SEP values were acceptable for most bioenergy traits, but exceeded $1.5 \%$ of the SEC by a limited extent for some traits (Table 3). To improve the accuracy of the final prediction equations, the validation samples were included in the calibration set and calibration equations were redeveloped using the same math treatments and options as in the original best calibrations (see rows "Combined" in Table 3). After including these additional samples, $r^{2}$ values improved to be greater than 0.8 for all traits except EE, UA, FETH, and CWE (all with $\left.r^{2}>0.76\right)$ and PENTP $\left(r^{2}=0.69\right)$. For the major sugars, PCA, FEST, and SSF products (ETOH and PENT) the $r^{2}$ values were greater than 0.90 . Combining the calibration and validations samples into a single combined calibration set also resulted in reduced SEC and SECV values for most traits. Another measure of the utility of calibrations is the ratio (RPD) of the standard deviation of the calibration samples (SD) to the standard error of prediction [36]. The RPD values greater than 2 indicate that the SEP is less than 0.5 the SD of the reference samples. The RPD ratios were typically greater than 2.2 for all major cell wall sugars, soluble sugars, ETOH, and PENT. The calibration results demonstrate that acceptable NIRS calibrations can be obtained for switchgrass biomass composition and SSF ethanol and soluble pentose yield.

Switchgrass Strain Differences for Actual and Theoretical Ethanol Yields

There were significant differences among the four check cultivars and experimental strains in the biomass yield trail for all traits in the strain evaluation trial including actual and theoretical ethanol yield per megagram and production per hectare (Table 4). The lowland cultivar, Kanlow had the highest biomass yields per hectare but its biomass also had the lowest SSF conversion efficiency. Ethanol yield from SSF (ETOHL) ranged from 98 to $115 \mathrm{~L} \mathrm{Mg}^{-1}$. Potential ethanol yield from released pentoses, assuming $80 \%$ conversion efficiency, ranged from 100 to $109 \mathrm{~L} \mathrm{Mg}^{-1}$. ETOHTL from

Table 5 Means and standard deviations (in parentheses) and correlations between calculated and NIRS predicted complex switchgrass biomass composition traits

\begin{tabular}{|c|c|c|c|}
\hline \multirow[t]{2}{*}{ Trait } & \multicolumn{2}{|l|}{ Means (SD) } & \multirow[t]{2}{*}{$r$} \\
\hline & Calculated from component values & NIRS-predicted values & \\
\hline & $\mathrm{g} \mathrm{kg}^{-1}$ & $\mathrm{~g} \mathrm{~kg}^{-1}$ & \\
\hline CWC & $712.6(22.16)$ & $703.0(22.7)$ & $0.88^{* *}$ \\
\hline AXMG & $250.1(9.8)$ & $252.2(9.7)$ & $0.99^{* *}$ \\
\hline $\mathrm{AX}$ & $235.9(10.1)$ & $237.7(7.7)$ & $0.84^{* *}$ \\
\hline $\mathrm{SC}$ & $37.6(10.7)$ & $40.5(11.5)$ & $0.97^{* *}$ \\
\hline NSC4 & $43.7(13.0)$ & $43.1(14.4)$ & $0.96^{* *}$ \\
\hline HEX & $370.9(13.7)$ & $374.6(15.0)$ & $0.95^{* *}$ \\
\hline SUG & $639.0(14.5)$ & $640.2(15.6)$ & $0.82^{* *}$ \\
\hline HEXE & $188.7(7.3)$ & $187.6(7.0)$ & $0.92^{* *}$ \\
\hline NSCE & $21.0(6.3)$ & $19.7(7.0)$ & $0.96^{* *}$ \\
\hline \multirow[t]{2}{*}{ CWE } & $61.9(5.7)$ & $64.1(4.5)$ & $0.77^{* *}$ \\
\hline & $\%$ & $\%$ & \\
\hline PSOL & $11.7(3.3)$ & $11.7(3.5)$ & $0.99^{* *}$ \\
\hline PPEN & 41.9 (1.6) & $42.1(1.6)$ & $0.93^{* *}$ \\
\hline CWEP & $40.9(4.6)$ & $40.4(4.04)$ & $0.95^{* *}$ \\
\hline PENTP & $76.6(3.3)$ & $76.8(2.3)$ & $0.88^{* *}$ \\
\hline HEXEP & $44.0(4.6)$ & $43.8(4.3)$ & $0.95^{* *}$ \\
\hline
\end{tabular}

$N=378$

${ }^{* *} p=0.01$, indicate significance 
both glucose and released pentoses ranged from 204 to $222 \mathrm{~L} \mathrm{Mg}^{-1}$. An experimental upland strain (NE 2229) that was bred for improved forage yield and IVDMD had the largest ETOHL and ETOHTL values. With the assay that was used in this study, NE 2,229 produced over $12 \mathrm{~L}$ more ethanol per megagram from SSF glucose than the cultivar Kanlow.

Because of the differences in biomass yield per hectare and actual and theoretical ethanol yield per megagram among the cultivars and experimental strains, there were very large differences in ethanol production per hectare (Table 4). The range in SSF ethanol production (ETOHTLH) from the hexoses was 2,533-3,719 $\mathrm{L} \mathrm{ha}^{-1}$ while the range in total theoretical ethanol production from all potential biomass sugars ranged from 4,877 to $7,887 \mathrm{~L} \mathrm{ha}^{-1}$. These large differences in ethanol production per hectare illustrate the need to optimize both biomass yield and conversion yield from biomass $\left(\mathrm{L} \mathrm{Mg}^{-1}\right)$ in switchgrass production systems. None of the cultivars and strains in this trial was bred for improved SSF ethanol yield, but several including Shawnee and NE 2229 were bred for improved forage digestibility which had a positive effect on SSF ethanol yield. The results demonstrate that genetic differences exist among switchgrass for conversion efficiency and indicate that a focused breeding effort should result in additional improvements in conversion efficiency.

Plant breeders and agronomists need to analyze a large number of biomass samples to develop improved plants and management practices that result in increased ethanol yields and production per hectare. In the ARS switchgrass breeding programs at Lincoln and Madison, WI, 5,00010,000 samples are generated per year per location for which composition and bioenergy conversion potential data is needed to efficiently bred for improved conversion efficiency. If done with conventional laboratory analyses, the wet laboratory work alone for the data listed in Table 4 for the switchgrass biomass yield test would have an approximate cost of over $\$ 110,000$ ( approximately $\$ 300$ per sample $\times 21$ entries $\times 6$ replicates $\times 3$ years $)$ without including equipment costs. NIRS analysis costs including equipment and technical support would be about $\$ 5$ per sample for a total of approximately $\$ 2,000$ for this experiment. Good NIRS calibrations provide the capacity to conduct such bioenergy analyses economically and rapidly. Composition and conversion efficiency data obtained from NIRS analyses of biomass samples also will enable researchers to identify which biomass components have the largest effect on conversion efficiency and to determine which are the most amenable to genetic or cultural practice modification.

Biomass composition traits such as cell wall concentration, total sugars, or hexose extraction efficiency listed in Table 4 were determined by calculation using NIRS predicted constituents of these traits and the equations listed in Table 1. It is also feasible to develop NIRS calibrations for these calculated traits (Table 3). For the samples from the switchgrass yield test, we determined the concentration of these multi-constituent traits by both calculations from NIRS-predicted component data and direct NIRS prediction of the composite traits. The calculated and direct NIRS predicted means and standard errors of these complex biomass components were very similar and were highly correlated (Table 5). This comparison demonstrates the accuracy and precision of the NIRS calibrations that were developed for switchgrass biomass composition and also the power of NIRS technology to predict complex feedstock traits. As biomass conversion technology is developed, it should be possible to develop NIRS calibrations for biorefinery products and co-products.

\section{Summary}

NIRS calibrations were developed for switchgrass biomass that can be used to accurately estimate over 20 biomass components including cell wall and soluble sugars, and ethanol and released pentose sugars from a laboratory SSF procedure. With this information, it is feasible to calculate an addition 13 complex feedstock traits including theoretical ethanol yield from hexoses and SSF hexose ethanol conversion efficiency. Using this NIRS-derived biomass data, we demonstrated that switchgrass cultivars and experimental strains adapted to the Midwest USA differ significantly for all biomass composition traits analyzed, and actual and theoretical ethanol yield per megagram and per hectare. These calibrations and their improved future versions can be used in all aspects of switchgrass research including basic genetics, breeding, production, harvest, and storage. It should be feasible to develop switchgrass cultivars with improved ethanol yields per megagram and production per hectare. With good NIRS calibrations, it should be possible for switchgrass biomass feedstock to be marketed and utilized on the basis of its ethanol yield potential.

\section{References}

1. Vogel KP, Jung HG (2001) Genetic modification of herbaceous plants for feed and fuel. Crit Rev Plant Sci 20:15-49

2. Roberts CA, Workman, J Jr, Reeves JB III (eds.) (2004) Nearinfrared spectroscopy in agriculture. Agron Monog 44. ASA, CSSA, and SSSA, Madison, WI.

3. Westerhaus M, Workman J, Reeves JB III, Mark H (2004). Quantitative analysis. In: Roberts CA, Workman J. Jr., Reeves JB (eds) Near-infrared spectroscopy in agriculture. Agron. Monog. 44. ASA, CSSA, and SSSA, Madison, WI, p 133-174

4. Shenk JS, Westerhaus MO (1991) Population definition, sample selection, and calibration procedures for near-infrared reflectance spectroscopy. Crop Sci 31:469-474 
5. Wold S, Geladi P, Esbensen K, Öhman J (1987) Multi-way principal components and PLS analysis. J Chemom 1:41-56

6. Wold S, Kettanehwold N, Skagerberg B (1989) Nonlinear PLS modeling. Chemom Intell Lab Syst 7:53-65

7. Himmel ME (2007) Biomass recalcitrance: engineering plants and enzymes for biofuels production. Science 306:982

8. Yanase H, Yamamoto K, Matsuda S, Yamamoto S, Okamoto K (2007) Genetic engineering of Zymobacter palmae for production of ethanol from xylose. Appl Environ Microbiol 73:25922599

9. Sanderson MA, Agblevor F, Collins M, Johnson DK (1966) Compositional analysis of biomass feedstocks by near infrared reflectance spectroscopy. Biomass and Bioenergy 111:365-370

10. Maranan MC, Laborie MPG (2007) Analysis of energy traits of Populus spp. clones by near-infrared spectroscopy. J Biobased Mater Bioenergy 1:155-165

11. Hames BR, Thomas SR, Sluiter AD, Roth CJ, Templeton DW (2003) Rapid biomass analysis - new tools for compositional analysis of corn stover feedstocks and process intermediates from ethanol production. Appl Biochem Biotechnol 105:5-16

12. Lamb JFS, Jung HG, Sheaffer CC, Samac DA (2007) Alfalfa leaf protein and stem cell wall polysaccharide yields under hay and biomass management systems. Crop Sci 47:1407-1415

13. Lorenz AJ, Coors JG, de Loen N, Wolfurm EJ, Hames BR, Sluiter AD, Weimer PJ (2009) Characterization, genetic variation, and combining ability of maize traits relevant to the production of cellulosic ethanol. Crop Sci 59:85-98

14. Lorenzana RE, Lewis MF, Jung HG, Bernardo R (2010) Quantitative trait loci and trait correlations for maize stover cell wall composition and glucose release for cellulosic ethanol. Crop Sci 50:541-555

15. Vogel KP, Brejda JJ, Walters DT, Buxton DR (2002) Switchgrass biomass production in the Midwest USA: harvest and nitrogen management. Agron J 94:413-420

16. Casler MD, Vogel KP, Taliaferro CM, Wynia RE (2004) Latitudinal adaptation of switchgrass populations. Crop Sci 44:293-403

17. Moore KJ, Moser LE, Vogel KP, Waller SS, Johnson BE, Pedersen JF (1991) Describing and quantifying growth stages of perennial forage grasses. Agron J 83:1073-1077

18. Varvel GE, Vogel KP, Mitchell RB, Follett RF, Kimble JM (2008) Comparison of corn and switchgrass on marginal soils for bioenergy. Biomass and Bioenergy 32:18-21

19. Vogel KP, Mitchell RB (2008) Heterosis in switchgrass: biomass yield in swards. Crop Sci 48:2159-2164

20. Murray I, Cowe, I (2004) Sample preparation. In: Roberts CA, Workman J Jr, Reeves JB III (eds) Near-infrared spectroscopy in agriculture. Agron Monog 44. ASA, CSSA, and SSSA, Madison, WI, p 75-112

21. Dien BS (2010) Mass balances and analytical methods for biomass pre-treatment experiments. In: Vertes A, Qureshi N, Yukawa $\mathrm{H}$, Blaschek $\mathrm{H}$ (eds) Biomass to biofuels: strategies for global industries. Wiley, United Kingdom, pp 213-231
22. Bremner JM (1996) Nitrogen - Total. p. 1085-1121. In Sparks DL et al. (ed.) Methods of soil analysis. Part 3. Chemical methods. SSSA Book Ser. 5. SSSA and ASA, Madison, WI.

23. Watson M E, Issac RA (1990) Analytical instruments for soil and plant analysis. In Westerman R (ed) Soil testing and plant analysis. (3rd Ed.). SSSA Book Ser. 3. SSSA, Madison, WI, p 691-704

24. Padmore JM (1990a) Fat (crude) or ether extract in animal feed. Method 920.39. In: Herlich K (ed). Official methods of analysis of Association of Official Analytical Chemists. 15th ed. Arlington, VA.

25. Dien BS, Jung HG, Vogel KP, Casler MD, Lamb JFS, Weimer PJ, Iten L, Mitchell RB, Sarath G (2006) Chemical composition and response to dilute-acid pretreatment and enzymatic saccharification of alfalfa, reed canarygrass, and switchgrass. Biomass Bioenergy 30:880-891

26. Smith D (1973) The nonstructural carbohydrates. In: Butler GW, Bailey RW (eds) Chemistry and biochemistry of herbage, vol 1. Academic, New York, pp 105-155

27. Theander O, Aman P, Westerlund E, Andersson R, Pettersson D (1995) Total dietary fiber determined as neutral sugar residues, uronic acid residues, and Klason lignin (the Uppsala method): collaborative study. J AOAC Int 78:1030-1044

28. Ahmed AER, Labavitch JM (1977) A simplified method for accurate determination of cell wall uronide content. J Food Biochem 1:361-365

29. Iiyama K, Lam TBT, Stone BA (1990) Phenolic acid bridges between olysaccharides and lignin in wheat internodes. Phytochemistry 29:733-737

30. Jung HG, Shalita-Jones SC (1990) Variation in the extractability of esterified $p$-coumaric and ferulic acids from forage cell walls. J Agric Food Chem 38:397-402

31. Dowe N, McMillan J (2001) SSF Experimental ProtocolsLignocellulosic Biomass Hydrolysis and Fermentation; Laboratory Analytical Procedure (LAP). National Renewable Energy Laboratory, NREL/TP-510-42630. Available at http://www.nrel. gov/biomass/pdfs/42630.pdf. Accessed 08 Jan 09.

32. Dien BS, Nagle N, Hicks KB, Singh V, Moreau RA, Tucker MP et al (2004) Fermentation of "Quick Fiber" produced from a modified corn-milling process into ethanol and recovery of corn fiber. Appl Biochem Biotechnol 113-116:937-949

33. Padmore JM (1990b) Protein (crude) in animal feed Dumas method. Method 968.06. In: Herlich K (eds) Official methods of analysis of Association of Official Analytical Chemists. 15th ed. Arlington, VA

34. Vogel KP, Pedersen JF, Masterson SD, Toy JJ (1999) Evaluation of a filter bag system for NDF, ADF, and IVDMD forage analysis. Crop Sci 39:276-279

35. SAS (2000-2004) SAS 9.1.3 help and documentation. SAS Institute Inc, Cary

36. Williams PC (1987) Variables affecting near-infrared reflectance spectroscopic analysis. In: Williams P, Norris K (eds) Nearinfrared technology in the agriculture and food industries. 1st Ed. Am Cereal Assoc Cereal Chem, St. Paul, MN. p 143-167 